\title{
Determining the Growth and Vitality of Micro-Organisms in Carpets and Mattresses in Non-Problem Dwellings by Measuring $\mathrm{CO}_{2}$ Released during Respiration
}

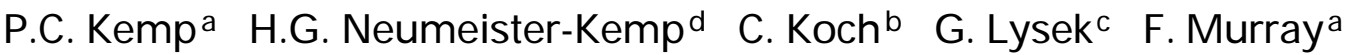 \\ aDivision of Science and Engineering, School of Environmental Science, Murdoch University, Perth, WA, Australia; \\ bInstitut für Landschaftsbau, Technische Universität Berlin, CInstitut für Systematische Botanik, \\ Fachbereich Biologie und dInstitut für Hygiene, Fachbereich Humanmedizin, Freie Universität Berlin, Germany
}

\section{Key Words}

Fungi · House dust - Fungal growth - Carpets .

Mattresses · Respiration

\begin{abstract}
Bedroom carpets and mattresses devoid of any reported or observed moisture damage or problems were analysed as sources of indoor fungal growth by determining the amount of $\mathrm{CO}_{2}$ released from respiration by microorganisms living in furnishings. Dust was extracted from the carpets and mattresses using a Kirby G5 vacuum cleaner. The basal respiration rate of the dust samples without moisture added was used to estimate base respiration rate and a substrate-induced respiration rate method was used to estimate the vitality of micro-organisms in the dust and to estimate the amount of living microbial biomass. Analysis of fungal species was performed by direct sprinkling of dust samples and stamping the filter collection papers directly onto a range of nutrient agars. Fungal differentiation revealed 18 species were living in the carpets and 12 species in the mattresses. Penicillium spp., Aspergillus niger and Zygomycetes were dominant fungi. The relative abundances of fungal species in the carpets were significantly correlated to the species in the mattresses. The basal $\mathrm{CO}_{2}$ respiration rate and the living microbial biomass from all
\end{abstract}

samples was the same as several soil types including sandy loam soils, Para Brown Earth, Sandy Brown Earth and Brown Podzol. The rate of respiration showed that the fungal species detected were living in the furnishings, and were highly metabolically active. This revealed that bedroom carpets and mattresses in non-problem dwellings and without moisture damage can provide a habitat with enough moisture to support fungal growth despite the lack of an obvious moisture source.

Copyright $\odot 2002$ S. Karger AG, Basel

\section{Introduction}

Recent concerns over the health implications of fungi in indoor air [1] have focussed current research on identifying the sources of fungal growth. However, studies of fungi indoors have provided limited and inconclusive information on the predictors of indoor fungal concentrations [2]. Even less is known of fungal prevalence in healthy (non-problem) buildings [3].

The factors that have been found to contribute to indoor fungal concentrations mostly relate to house dust. Early research by Maunsell [4] and Richards [5] found that dust-raising activities such as cleaning and construction work contributed significantly and this has been confirmed by more recent studies [6-9]. Other factors include

\section{KARGER \\ Fax +4161306 1234 \\ E-Mail karger@karger.ch \\ www.karger.com

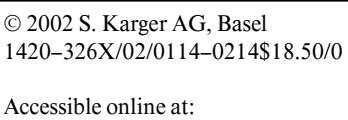

Dr. Peter Kemp

School of Environmental Science, Murdoch University

Murdoch, WA 6150 (Australia)

Tel. +61 (0) 89243 8501, Fax +61 (0) 893104997

E-Mail pkemp@central.murdoch.edu.au 
the presence of textile flooring [10], wall-to-wall carpet [11-13]; occupants at home most of the time; presence of pets; the type of flooring [13]; furniture as a major source of meso-hygrophilic Penicillium spp. spores [14], and the movement of people, pets, vacuum cleaning and construction work [9]. Higher concentrations occur up to $1 \mathrm{~m}$ above carpeted flooring compared to bare floors [15]. These factors are suggested to be responsible for the large variations in indoor air concentrations [1] that range from 1 up to $6,000 \mathrm{CFU} \cdot \mathrm{m}^{-3}$ [7].

Carpets in particular have become a concern as they present a large surface of fleecy material that accumulates dirt and debris (including micro-organisms) that is transported indoors from the outdoors [16] on shoes, pets and food [17]. Children and pets in particular substantially increase the amount of soil that is transported into homes [18]. This accumulated house dust is well recognised as a major source of allergens in non-industrial indoor environments [13]. In particular, exposure to micro-organisms and their products in house dust is considered to be the most probable causative agent in allergic and/or immunotoxic respiratory disorders, especially when dust mite numbers are low [19].

House dust has been characterised as a complex mixture of different particles which range in size from $1 \mu \mathrm{m}$ up to $1 \mathrm{~mm}$ in diameter [20]. It is known to contain allergens from various sources including pyroglyphid (house dust) mites [21], animal dander [22-24], fungi [22, 23, 25, 26], dead insects, algae, pollen, and bacteria [22]. House dust also includes particles of fibres, hairs, paint chips, sand, and combustion products [22]. House dust is also a reservoir of volatile and semivolatile organic compounds including organic acids, aldehydes and $n$-alkanes [20].

Many studies have investigated microbial concentrations and compositions in house dust and have shown that a large number and a wide range of micro-organisms are present [27]. Of the contaminants in house dust, fungi are of particular significance as they produce a substantially greater biomass than other micro-organisms in house dust. They produce a wide range of toxins and allergens and a considerable number of species are human pathogens [28]. Because of their wide range of moisture and nutrient tolerance, some fungi even have the potential to grow best in house dust $[29,30]$

The results from previous studies highlight the need for further research of the microbial ecology of carpets (and other soft furnishings), and to understand how airborne bio-contamination levels relate to surface contamination [18]. To date, the only evidence presented in the literature on whether the fungi are living (growing) in indoor fur- nishings is circumstantial evidence from studies where fungal species in furnishings are not typical or dominant indoor or outdoor air species, and their presence, therefore, is not due to sedimentation of spores out of the air [17].

One method of determining direct evidence of microbial growth is to measure the evolution of carbon dioxide $\left(\mathrm{CO}_{2}\right)$ from respiration by placing samples in an airtight chamber. The authors are only aware of one study on $\mathrm{CO}_{2}$ evolution from air filter materials [31] and two investigations of $\mathrm{CO}_{2}$ evolution from house dust from non-problem buildings in the literature [20,32]. However, the study by Pasanen et al. [32] measured the growth of a known fungus on sterilised house dust. The study by Korpi et al. [20] appears to be the only study to use house dust with its whole variety of micro-organisms that are naturally present.

Soil microbial respiration, on the other hand, is a wellestablished method for estimating soil microbial activity since the late 19th century [33] and is still one of the most used and useful measures of soil microbial activity [34]. This standardised soil respiration method could be used for estimating the health of microbes in house dust; for the reason that the characteristics of soils should be similar to that of house dust which is derived from dirt and debris from the ground outdoors that has been transported indoors.

This experiment tests the hypothesis that fungi in bedroom carpets and mattresses in non-problem buildings are growing and reproducing in the habitat they provide despite the lack of any reported or evident moisture source. This can be tested by extracting dust from the interior carpets and furnishings and measuring the amount of $\mathrm{CO}_{2}$ released from respiration.

\section{Methods}

The dust from bedroom carpets and mattresses from six apartments in Berlin (Germany) was collected and analysed for living microbial biomass and fungal contamination (number of samples = 52).

\section{Dwelling Characteristics}

A checklist and a questionnaire by interview [of the principal occupant(s)] were used to characterise variables in the homes that have been reported to be associated with the presence of fungal propagules in house dust reported by Verhoeff et al. [35]. The checklist included type of dwelling, ventilation facilities, heating facilities, building materials, insulation of the dwelling, design of the house, type of flooring and type of mattresses, and observations of moisture problems such as damp patches and/or fungal growth on outer or 
inner walls, ceilings and floors. The questionnaire included the number of occupants, presence of pets, cleaning regime, age of flooring and mattresses and visible signs of dampness during the last 2 years.

Fourteen dwellings were assessed for use in the study. Only 6 were considered non-problem dwellings and were included in the study. These 6 dwellings had the following characteristics: naturally ventilated; no reported dampness or flooding; no damp spots or fungal growth on the mattresses; carpeted flooring in the bedrooms and more than $50 \%$ of the dwelling; laundry was not dried in the home; constructed after 1975; occupants were not home most of the time; no pets; possibility to regulate heating in the bedrooms; no furniture hard against the outer wall; no mould patches on the inner wall and no damp patches on the outer wall.

All carpets were domestic quality nylon level loop or nylon cut pile and between 3 and 7 years old. The carpet conditions ranged from good to fair wear with light soiling. None of the carpets had a flooding history. All mattresses were inner spring type and were between 6 months and 5 years old.

\section{Collection of Dust Samples}

The vacuum cleaning equipment selected for collection of dust was a Kirby G5 Micromagic Filtration vacuum cleaner (Kirby Vacuum, Cleveland, USA). Carpet dust samples were collected in a standard vacuum bag (Kirby Certified HEPA Micron Magic Filtration) with a $0.3-\mu \mathrm{m}$ pore size.

The carpet surfaces of all the bedrooms in each apartment/house were vacuumed with three passes over the same place with the beating head engaged. Samples at each house were collected in one vacuum cleaner bag.

The entire surface of all mattresses in each apartment or house were vacuumed for approximately $1 \mathrm{~min}$ with the beating head engaged. The mattress dust samples were collected in a single vacuum cleaner bag.

All vacuum cleaner bags were transported in a sterile plastic bag tied at the top to maintain the moisture content. All samples were processed within $24 \mathrm{~h}$.

\section{Respiration Activity}

The dust samples were analysed for living microbial biomass by measuring the amount of $\mathrm{CO}_{2}$ evolution from respiration.

A respirometer, Respicond III (A. Nordgren Innovations AB, Umeå, Sweden), was used to measure $\mathrm{CO}_{2}$ production $( \pm 1 \%)$. The apparatus was based on the description of the conductivity cell by Nordgren [36] and is based on the principle that $\mathrm{CO}_{2}$ absorbed in a hydroxide solution forms carbonate ions and decreases the conductivity which is calibrated against $\mathrm{CO}_{2}$ absorption. The decomposition of carbon compounds is mainly performed by fungi and to a lesser extent bacteria [37]. The $\mathrm{CO}_{2}$ evolution data was moved to a spreadsheet programme where the microbial parameters were calculated after deduction of the blanks. Seven replicates were measured for each sample. Altogether, 7 blanks were evenly distributed among the sample jars.

The complete system consisted of a series of jars connected to a conductivity meter via a multiplexer that connected each unit in turn as described by Nordgren [36]. The jars were placed in water baths to maintain a constant temperature of $22^{\circ} \mathrm{C}$ for calculation of microbial biomass [38]. Three grams of sample was added to each jar. The $\mathrm{CO}_{2}$ evolution (respiration) from an unamended dust as well as the decomposition were monitored every hour [37]. The total length of time for the test was 8 days. Potassium hydroxide solutions of 0.05 and $0.3 M$ were used as the electrolytes [36]. The jars containing the samples were constructed of autoclavable standard plastics (Nalge $2117,250 \mathrm{ml}$ and Nalge 2118, $30 \mathrm{ml}$ ) [36].

Samples were prepared following the instructions in Torstensson [37]. The moisture content before analysis was $<400 \%$ of the organic matter content. The loss on ignition, dry weight of the sieved soil, and $\mathrm{pH}\left(\mathrm{H}_{2} \mathrm{O}\right)$ were also determined. The soil was homogenised by sieving (mesh approximately $0.5 \mathrm{~cm}$ ) in order to be able to mix it thoroughly with the glucose powder [37].

The base respiration rate is a measure of the total microbial activity and was measured using the samples in original state with no moisture added (unamended) [34]. It was calculated as the average of the hourly respiration rates during a stable period over several days. Base respiration rate is reported in micrograms of carbon dioxide per gram of dust per hour $\left[\mathrm{CO}_{2}(\mu \mathrm{g}) \mathrm{g}^{-1} \mathrm{~h}^{-1}\right]$.

The substrate-induced respiration rate (SIR, a second part of the measurement) determines the vitality of the living microbes by calculating the increased rate of $\mathrm{CO}_{2}$ production after adding an easily degraded nutrient (glucose) to the samples. Living cells instantaneously absorb the glucose added and produce carbon dioxide at a rate that was constant until the organisms start to grow [38]. SIR was calculated as an average of the lowest values where the respiration was constant after glucose addition [37]. A mixture of $80 \mathrm{~g}$ glucose, $13 \mathrm{~g}\left(\mathrm{NH}_{4}\right)_{2} \mathrm{SO}_{4}$ and $2 \mathrm{~g} \mathrm{KH}_{2} \mathrm{PO}_{4}$ [37] was thoroughly ground and mixed in a mortar and stored at room temperature. After 2-3 days of measuring the basal respiration, $0.2 \mathrm{~g}$ of the glucose mixture was added to each sample and vigorously shaken. The SIR is reported in $\mathrm{CO}_{2}(\mu \mathrm{g}) \mathrm{g}^{-1} \mathrm{~h}^{-1}$.

The lag time is the time from addition of glucose until exponential growth starts. It reflects the vitality of the growing organisms [34]. It is calculated from a plot of the logarithm of the respiration rate and measured in hours [37]. The exponential phase of the growth appears linear and a regression was made giving the growth constant and the intercept with the y axis. The following formula was used to calculate the regression [37]:

$$
\text { lag time }=\mu^{-1}(\log \text { SIR }-\mathrm{y} \text { intercept })-\text { time of glucose addition }
$$

The microbial biomass of the dust samples was estimated using the maximum initial respiration rate and substituting this value into the following regression formulae [38]:

$$
\mathrm{x}=40.4 \mathrm{y}+0.37
$$

where: $\mathrm{y}=$ maximum initial rate of respiration $\left(\mathrm{CO}_{2}\right.$ unit dust $\left.{ }^{-1} \mathrm{~h}^{-1}\right)$, $\mathrm{x}=\mathrm{mg}$ microbial $\mathrm{C}$ unit dust $\mathrm{t}^{-1}$

The microbial biomass is reported in milligrams of carbon per gram of dust [C (mg) $100 \mathrm{~g}^{-1}$ dust].

\section{Fungal Analysis}

The relative numbers of fungal species were determined in the dust samples. Direct plating was chosen as it is a method that detects a wider range of fungal species than dilution plating [13].

Direct Plating Method. Coarse material such as hairs and litter was removed from all dust samples before further processing. For direct sprinkle plating, $0.1 \mathrm{mg}$ of dust was sprinkled from the filter paper into a series of 5 Petri dishes (of the same agar) using sterile glass or stainless steel spreaders. A total of $0.5 \mathrm{mg}$ dust was spread across 25 plates (i.e. 5 replicates of 5 different agar media).

Filter Paper Stamping Method. After removing samples for direct and dilution plating, a $2-\mathrm{cm}^{2}$ piece was cut from the filter paper and placed lightly onto MEA agar 3 times and then left on the agar the 4th 
time. This method was used as it increased the range of species that could be differentiated. However this is not a reliable method for quantifying the number of fungi because the dust samples are usually heavily contaminated and the stamped area of nutrient agar is normally overgrown with uncountable numbers of colony forming units.

\section{Incubation and Nutrient Media}

A detailed description of incubation and counting has been previously published in Kemp et al. [39]. In brief, nutrient agar was incubated at $20 \pm 2{ }^{\circ} \mathrm{C} 30-40 \%$ RH (Heraeus, Hanau, Type BK $5060 \mathrm{E})$. The following media were incubated in the dark with no direct sunlight: malt extract agar (MEA); Czapek-Dox agar (Oxoid CM 95, modified); MEA + 40\% sucrose; Dichloran 18\% glycerol agar (DG 18, Oxoid M 729), and rose bengal. Synthetic low-nutrient agar [40] was incubated under UV light (Desage, Heidelberg, Type MinUVIS, UV $366 \mathrm{~nm}$ ) with sterile filter paper laid on the surface. Chloramphenicol was added to all agar to limit bacterial growth. Extra MEA plates were incubated at $37^{\circ} \mathrm{C}$ for differentiation of Aspergillus fumigatus.

Microscopic inspection was performed with a $\times 40$ and $\times 100$ objective magnification to determine the morphological characteristics of fungi. The method used for differentiation of fungi was based on the methodology first described in detail by Kircheis [41]. Differentiation by genus and species was done with the aid of identification literature and the Hughes-Tubaki-Barron system and Saccardo system [see ref. 39]. Fungal colonies that did not produce spores or conidia and were not able to be identified were classified as sterile mycelia.

\section{Statistical Methods}

Samples were checked for analysis of variance by performing paired $t$ tests assuming equal variance and alpha $=0.05$ using the MS Excel 5.0 Statistical Add-ins Package (Microsoft). Regression analysis was performed using the MS Excel 5.0 Statistical Add-ins Package. Bivariate correlation was performed to calculate the Pearson correlation ( $\rho$ ) using a two-tailed test for significance $(p)$ in the statistical software package SPSS for Windows Release 9.0.1 (SPSS Inc.).

\section{Results}

\section{Respiration Activity}

The base respiration rate of micro-organisms in the dust without moisture added was not significantly different ( $\mathrm{p} \leq 0.001)$ between the carpet dust and mattress dust (table 1).

The lag time for SIR to begin for the mattress dust was twice as long the carpet dust.

The period of exponential increase in $\mathrm{CO}_{2}$ production until maximum SIR rate was virtually the same for both samples.

The maximum initial respiration rate (as a function of the SIR) was highest for the mattress dust and was significantly different to the carpet dust samples $(\mathrm{p}<0.036)$. The maximum initial respiration rate for both the carpet
Table 1. Respiration and fungal species in carpets and mattresses

\section{Carpets}

Inner-spring mattresses

\section{Respiration rate (mean, $S D$ )}

Samples

Base respiration rate, $\mu \mathrm{g} \mathrm{CO}_{2} \mathrm{~g}^{-1} \mathrm{~h}^{-1}$

Lag time, $\mathrm{h}$ 7

Time till peak, $\mathrm{h}$

$6.3(1.4)$

Max initial respi

$$
\text { (SIR), } \mu \mathrm{g} \mathrm{CO}_{2} \mathrm{~g}^{-1} \mathrm{~h}^{-1}
$$

SIR $^{\mathrm{a}}, \mathrm{ml} \mathrm{CO}_{2} 100 \mathrm{~g}^{-1}$ dust h$^{-1}$

Living microbial biomass

$$
\mathrm{C}(\mu \mathrm{g}) \mathrm{g}^{-1} \text { dust }
$$

\section{Fungal Species}

Samples

$259(46)$

$288(35)$

Acremonium spec.

Alternaria alternata

Aspergillus spp.

Aspergillus flavus

Aspergillus niger

Aureobasidium pullulans

Botrytis cinerea

Cladosporium cladosporoides (culmorum)

Cladosporium herbarum

Fusarium spp.

Nigrospora spec.

Paecilomyces variotii

Penicillium spp.

Trichoderma viride

Zygomycetes

Mucor hiemalis

Rhizopus stolinifer

Yeasts (Sporobolomyces roseus and Candida albicans)

Sterile mycelia

Other fungi

Total ${ }^{b}$

$\begin{array}{ll}35 & 30 \\ \text { C } & - \\ \text { B } & \text { B } \\ \text { B } & \text { A } \\ - & \text { C } \\ \text { B } & \text { A } \\ \text { C } & \text { C } \\ \text { C } & \text { C }\end{array}$

30
-
B
A
C
A
C
C

B -

B -

C B

C -

$\mathrm{C}-$

A A

C - -

A A

B - -

B $\quad$ B

B C

$\mathrm{C}-\mathrm{C}$

C C

$18 \quad 12$

$\mathrm{A}=$ Dominant species $\left(6 \times 10^{5}\right.$ to $\left.10^{6} \mathrm{CFU} \cdot \mathrm{g}^{-1}\right) ; \mathrm{B}=$ detected in moderate numbers $\left(3 \times 10^{5}\right.$ to $\left.6 \times 10^{5} \mathrm{CFU} \cdot \mathrm{g}^{-1}\right) ; \mathrm{C}=$ detected in low numbers $\left(1 \times 10^{4}\right.$ to $\left.3 \times 10^{5} \mathrm{CFU} \cdot \mathrm{g}^{-1}\right) ;-=$ not detected (below detection level of $1 \mathrm{CFU}$ per plate $\left(10^{4} \mathrm{CFU} \cdot \mathrm{g}^{-1}\right)$.

a SIR as reported in soil science studies.

b Number of fungal species.

and mattress samples were double their base respiration rate. There was a significant difference between the base respiration rate and the maximum initial respiration rate for all samples $(\mathrm{p}<0.032)$.

The living microbial biomass estimation was based on the maximum initial respiration rate and therefore reflects those results. The mattress dust had the highest 
amount of living microbial biomass which was $11 \%$ higher, which was significantly different $(p<0.035)$ from the carpet dust.

\section{Fungal Species in the Carpets and Furnishings}

Fungal differentiation revealed that a different range of fungi were extracted from each of the different furnishing types (table 1). A total of 21 fungi were differentiated and 18 species were identified. All species except Aspergillus flavus occurred in the carpet dust and 12 species occurred in the mattress dust.

Penicillium spp. and Zygomycetes were dominant fungi in both samples. Cladosporium spp. and Mucor only occurred in carpet dust but not in mattress dust. Aspergillus niger (in the mattress dust) was the only single species that occurred as a dominant fungus.

Despite these differences, there was a significant correlation $(\rho=0.728, p<0.000)$ between the occurrence of fungal species in the carpet dust and the mattress dust.

\section{Fungal Counts}

Although useful for identification of species and genera, the colonies grown from the direct sprinkling method were either too numerous or were too close to adjacent colonies to count for all samples. This relates to a CFU count greater than $100 \mathrm{CFU}$ per plate equating to greater than $10^{6} \mathrm{CFU} \cdot \mathrm{g}^{-1}$. Even trials using smaller quantities of dust produced uncountable numbers of colonies on the plates. The values attributed to species in table 1 are therefore based on the relative abundance of each species and not on CFU counts.

\section{Discussion}

\section{Respiration and Biomass}

The results show for the first time that fungi encounter conditions that are suitable for them to grow in bedroom carpets and mattresses which are kept in a dry condition (in non-problem buildings and without moisture damage). The base respiration rate of the dust (with no added moisture) showed that the microbial activity was equivalent to sandy loam soil, Para Brown Earth, Sandy Brown Earth and Brown Podzol [36, 38, 42, 44]. The micro-organisms in the carpet and mattress dust were very healthy as the SIR after glucose addition was twice the amount measured in these soils. This indicates that the living microbial biomass had a high metabolic activity.
The microbial biomass in the carpet dust $\left(259 \mu \mathrm{g} \mathrm{g}^{-1}\right.$ soil) samples was higher than the amount measured in sandy loam soil $\left(222 \mu \mathrm{g} \mathrm{g}^{-1}\right.$ soil) [42], Para Brown Earth (130-188 $\mu \mathrm{g} \mathrm{g}^{-1}$ soil) [38, 44], Sandy Brown Earth $(250 \mu \mathrm{g}$ $\mathrm{g}^{-1}$ soil) and Brown Podzol (300 $\mu \mathrm{g} \mathrm{g}^{-1}$ soil) [38].

The significance of knowing the amount of microbial biomass is that it increases or decreases much more quickly than organic matter (in soils) [42]. This has implications for the increased growth of fungal contaminants especially after increased moisture availability from accidental spills. The biomass in most soils is about $1-3 \%$ of organic matter $[45,46]$ and the results suggest that the biomass in dust would be similar. The ratio of biomass carbon to soil organic carbon has been a useful indicator for changing soil conditions (e.g. in the presence of heavy metals) and the ratio suggested in the dust shows that conditions for growth in the dust were as good as or slightly better than those encountered in soils.

The speciation of fungi also revealed that the carpets and mattresses supported a similar range and relative abundance of fungal species. However the fungal species cover a wide range of moisture and nutrient requirements. This has also been reported in other studies of floor dust [13, 14, 27, 47, 48], carpet dust [42], mattress dust [21, 47, 49], and furniture dust [14].

\section{Moisture Requirements}

While the moisture content of the dust samples was not determined, there is an inference that moisture levels were high enough to support fungi that require a high water activity $\left(\mathrm{a}_{\mathrm{w}} 0.90\right)$ in the substrate. These include A. niger, Aureobasidium, Trichoderma, Fusarium, and some yeasts [50]. The majority of the fungi detected require a moderate water activity in their substrate $\left(a_{w}\right.$ 0.85-0.9) [50]. However, the furnishings were all free of moisture damage and were kept in good order.

Sources of moisture not determined in the initial inspection and interview included moisture produced by the user which can increase the moisture levels in furnishings [14] and accidental wetting or dampness on carpets is a common problem in all climates [16]. Occupant activities such as cooking and showering can also substantially increase relative humidities inside dwellings and may provide a further source for moisture in interior furnishings.

It is important to note that the results indicate a relative absence of xerophilic fungi. However, it was found that $A$. niger and several other fungi that normally require higher water activity were being cultivated and showed substantial growth on xerophilic agar. While it is possible 
that conditions of higher humidity exist in the buildings (at least occasionally), an alternative explanation for the growth of mesophilic fungi on xerophilic agar is their opportunistic adaptation to their habitat.

\section{Furnishings as Habitats for Fungal Growth}

The study confirms the correlations between increased fungi and the presence of carpeted floors [13] and in mattresses [51] and suggests that these correlations were due to fungal growth in interior furnishings. The study also confirms the conclusions of other researchers where the frequency and magnitude of occurrence of individual species such as A. niger, Aureobasidium pullulans and Penicillium herbarum in bedroom carpet dust were attributed to these fungi growing in the carpets rather than influx from other sources [17]. The fungi found in the mattresses cannot be sourced from atmospheric deposition as these are covered virtually all the time with sheets and blankets.

\section{Fungal Respiration}

While fungi are not the only micro-organisms present in house dust, they are the largest producer of $\mathrm{CO}_{2}$ in soils and the ratio of fungi to bacteria range from $1: 4$ to $1: 9[38$, 37].

\section{Conclusions}

The study showed that bedroom carpets and mattresses provided a habitat with enough moisture to sustain fungal growth despite the fact that they were kept in good order and were devoid of moisture or water damage. The fungal growth was not limited to xerophilic fungi as most of the fungi detected require a higher moisture content in the substrate. The amount of growth was substantial as the rate of respiration showed that the fungal species living in the carpets and mattresses were highly metabolically active and were present in similar quantities to those found in several soil types. This study confirms that associations between increased indoor populations of fungi and carpeting may be due to fungi living and growing in the carpets.

\section{Acknowledgements}

The authors would like to thank Maike Fuchs, who prepared and operated the apparatus used for the $\mathrm{CO}_{2}$ measurements. We thank Mr. Puhlmann of Puhlmann GmbH Berlin, Germany for his support in supplying the Kirby G5 vacuum cleaner used in the experiments. We would also like to thank Angelika Nickelmann and Michael Hesse for their help in differentiating the fungi.

\section{References}

1 Flannigan B, Miller JD: Health implications of fungi in indoor environments - an overview; in Samson RA, Flannigan B, Flannigan ME, Verhoeff AP, Adan OCG, Hoekstra ES (eds): Health Implications of Fungi in Indoor Environments. Amsterdam, Elsevier, 1994, pp 3 28.

2 Dharmage S, Bailey M, Raven J, Mitakakis T, Thien F, Forbes A, Guest D, Abramson M, Walters EH: Prevalence and residential determinants of fungi within homes in Melbourne Australia. Clin Exp Allergy 1999;29:14811489.

3 Yang C: Understanding the biology of fungi found indoors; in Proc Int Conf Fungi and Bacteria in Indoor Environments: Health Effects, Detection and Remediation, Saratoga Springs, 1994, p 131.

4 Maunsell K: Airborne fungal spores before and after raising dust. Int Arch Allergy 1952;3:93102.

5 Richards M: Atmospheric mould spores in and out of doors. J Allergy 1954;25:429-439.

6 Burge HP, Boise J, Solomon WR, Bandera E: Fungi in libraries: An aerometric survey. Mycopathologia 1978;64:67-72.
7 Solomon WR, Burge HA: Allergens and Pathogens; in Walsh PJ, Dudney CS, Copenhaver EP (eds): Indoor Air Quality. Boca Raton, CRC Press, 1984, pp 173-194.

8 Burge HA: Fungus allergens. Clin Rev Allergy 1985;3:319-329.

9 Hunter CA, Grant C, Flannigan B, Bravery AF: Mould in buildings: The air spora of domestic dwellings. Int Biodeterioration 1988;24:81101.

10 Dales RE, Miller D, White J: Testing the association between residential fungus and health using ergosterol measures and cough recordings. Mycopathologia 1999;147:21-27.

11 Gravesen S, Larsen L, Gyntelburg F, Skov P: Demonstration of micro-organism and dust in schools and offices. Allergy 1986;41:520-525.

12 Dybendal T, Vik H, Elsayed S: Dust from carpet and smooth floors. II. Antigenic and allergenic content of dust vacuumed from carpet and smooth floors in schools under routine cleaning schedules. Allergy 1989;44:401-411.

13 Wanner H, Verhoeff AP, Colombi A, Flannigan B, Gravesen S, Mouilleseux A, Nevalainen A, Papadakis J, Seidel K: European Collaborative Action: Indoor air quality and its impact on man: Environmental quality and life. Rep No 12: Biological Particles in Indoor Environments, 1993.
14 Schober G: Fungi in carpet and furniture dust. Allergy 1991;54:209-212.

15 Gravesen S, Larsen L, Skov P: Aerobiology of schools and public institutions: Part of a study. Ecol Dis 1983;2:411-413.

16 Flannigan B, Morey PR: Control of moisture problems affecting biological indoor air quality. ISIAQ guideline: Task Force 1. Int Soc Indoor Air Quality and Climate, Ottawa, 1996.

17 Beguin H: Mould biodiversity in homes. II. Analysis of mattress dust. Aerobiologica 1995; 11:3-10.

18 Cole EC, Foarde KK, Leese KE, Green DA, Franke DL, Berry MA: Assessment of fungi in carpeted environments; in Samson RA, Flannigan B, Flannigan ME, Verhoeff AP, Adan OCG, Hoekstra ES (eds): Health Implications of Fungi in Indoor Environments. Amsterdam, Elsevier, 1994, pp 103-128.

19 Horak B, Dutkiewicz J, Solarz K: Microflora and acarofauna of bed dust from homes in Upper Silesia, Poland. Ann Allergy Asthma Immunol 1996;76:41-50.

20 Korpi A, Pasanen A-L, Pasanen P, Kalliokoski P: Microbial growth and metabolism in house dust. Int Biodeterioration Biodegrad 1997;40: 19-27. 
21 Platts-Mills TAE, De Weck AL: Dust mite allergens and asthma: A worldwide problem. International workshop report. Bull World Health Organ 1988;66:769-780.

22 Verhoeff AP, Hoekstra ES, Samson RA, Brunekreef B, van Wijnen JH: Fungal propagules in house dust. I. Comparison of analytical methods and their value as estimators of potential exposure. Allergy 1994;49:533-539.

23 Wood R, Eggleston PA, Lind P, Ingemann L, Scwartz B, Gravesen S, Terry D, Wheeler B, Adkinson NF: Antigenic analysis of house dust samples. Am Rev Respir Dis 1988;137:358363.

24 Luczynska CM, Li Y, Chapman MD, PlattsMills TAE: Airborne concentrations and particle size distribution of allergen derived from domestic cats (Felis domesticus). Am Rev Respir Dis 1990;141:361-367.

25 Gravesen S: Identification and prevalence of culturable mesophilic microfungi in house dust from 100 Danish homes. Allergy 1978;33:268.

26 Wickman M, Gravesen S, Nordvall SL, Pershagen $\mathrm{G}$, Sundell J: Indoor viable dust bound microfungi in relation to residential characteristics, living habits, and symptoms in atopic and control children. J Allergy Clin Immuno 1992;89:752-759.

27 Flannigan B, Vicars S, Pasanen A, Pasanen P. Bioaerosols from house dust; in Samson RA, Flannigan B, Flannigan ME, Verhoeff AP Adan OCG, Hoekstra ES (eds): Health Implications of Fungi in Indoor Environments. Amsterdam, Elsevier, 1994, pp 65-74.

28 Jennings DH, Lysek G: Fungal Biology, ed 2. Oxford, BIOS, 1999

29 Lustgraaf B: Xerophilic fungi in mattress dust. Mykosen 1977;20:101-106.

30 Samson RA, Flannigan B, Flannigan ME, Verhoeff AP, Adan OCG, Hoekstra ES (eds): Health Implications of Fungi in Indoor Environments. Amsterdam, Elsevier, 1994, pp 531538.

31 Martikainen PJ, Asikainen A, Nevalainen A, Jantunen M, Pasanen P, Kalliokoski P: Microbial growth on ventilation filter materials; in Proc 5th Int Conf on Indoor Air Quality and Climate. Toronto, Walkinshaw, 1990, pp 203 206.
32 Pasanen P, Korpi A, Kalliokoski P, Pasanen AL: Growth and metabolite production of Aspergillus versicolor in house dust. Environ Int 1997;23:425-432.

33 Domsch KH: Bodenatmung: Sammelbericht über Methoden Ergebnisse. Zentralbl Bacteriol Parasitenkd Infektkr Abt 2 1961;116:33-78.

34 Nordgren A, Baath E, Söderström B: Evaluation of soil respiration characteristics to assess heavy metal effects on soil micro-organisms using glutamic acid as a substrate. Soil Biol Biochem 1988;20:949-954.

35 Verhoeff AP, van Wijnen JH, Hoekstra ES, Samson RA, van Strien RT, Brunekreef B: Fungal propagules in house dust. II. Relation with residential characteristics and respiratory symptoms. Allergy 1994;49:540-547.

36 Nordgren A: Apparatus for the continuous long-term monitoring of soil respiration rate in large numbers of samples. Soil Biol Biochem 1988;20:955-958.

37 Torstensson LT (ed): Soil biological variables in environmental hazard assessment. MATS Guideline Test 16, Rep No 4262, 1994, pp 140-166.

38 Anderson JPE, Domsch KH: A physiological method for the quantitative measurement of microbial biomass in soils. Soil Biol Biochem 1978;10:215-221.

39 Kemp PC, Neumeister-Kemp HG, Lysek G, Murray F: Survival and growth of micro-organisms on air filtration media during initial loading. Atmos Environ 2001;35:4739-4749.

40 Nirenberg HI: Untersuchung über die morphologische und biologische Differenzierung in der Fusarium-Sektion Liseola. Mitt biol Bundesanstalt Land- Forstwirtschaft Berlin-Dahlem 1976;169:1-117.

41 Kircheis U: Ökotoxikologische Untersuchungen an Pilzen zur Artverschiebung auf Luftfiltern von Klimaanlagen; Diplomarbeit Zentralbibliothek der Freien Universität von Berlin, 1997.

42 Beguin $\mathrm{H}$, Nolard N: Prevalence of fungi in carpeted floor environment: Analysis of dust samples from living room floors, bedrooms, offices and school classrooms. Aerobiologia 1996;12: 113-120.
43 Chander K, Brookes PC: Effects of heavy metals from past applications of sewage sludge on microbial biomass and organic matter accumulation in a sandy loam and silty loam U.K. soil. Soil Biol Biochem 1991;23:927-932.

44 Koch C, Frölich E, Wilke B-M: Ökotoxikologische Untersuchungen von kontaminiertem/ dekontaminiertem Bodenfeinkorn. Zentralbibliothek Technische Universität Berlin, 1998.

45 Jenkinson DS, Ladd JN: Microbial biomass in soil: Measurement and turnover; in Paul EA, Ladd JN (eds): Soil Biochemistry. New York, Dekker, 1981, vol 5, pp 415-471.

46 Anderson TH, Domsch KH: Ratios of microbial biomass carbon to total organic carbon in arable soils. Soil Biol Biochem 1989;21:471479.

47 Hoekstra ES, Samson RA, Verhoeff AP: Fungal propagules in house dust: A qualitative analysis; in Samson RA, Flannigan B, Flannigan ME, Verhoeff AP, Adan OCG, Hoekstra ES (eds): Health Implications of Fungi in Indoor Environments. Amsterdam, Elsevier, 1994 pp169-177.

48 Takatori K, Lee H, Ohta T, Shida T: Composition of the house dust mycoflora in Japanese houses; in Samson RA, Flannigan B, Flannigan ME, Verhoeff AP, Adan OCG, Hoekstra ES (eds): Health Implications of Fungi in Indoor Environments. Amsterdam, Elsevier, 1994, pp 93-101.

49 Ozyaral O, Germeyan H, Johansson CB: House dust mold in Istanbul. I. Detection of mold flora in bed dust. Mikrobiyol Bul 1988;22:41-60.

50 Samson RA, van der Lustgraaf B: Aspergillus penicilloides and Eurotium halophilicum in association with house dust mites. Mycopathologia 1978;64:13-16.

51 Summerbell RC, Staib F, Dales R, Nolard N, Kane J, Zwanenburg H, Burnett R, Krajden S, Fung D, Leong D: Ecology of fungi in human dwellings. J Med Vet Mycol 1992;30(suppl 1): 279-285. 